\title{
IODP Expedition 339 in the Gulf of Cadiz and off West Iberia: decoding the environmental significance of the Mediterranean outflow water and its global influence
}

\author{
F. J. Hernández-Molina ${ }^{1}$, D. Stow ${ }^{2}$, C. Alvarez-Zarikian ${ }^{3}$, and Expedition IODP 339 Scientists \\ ${ }^{1}$ Department of Earth Sciences, Royal Holloway University of London, Egham, Surrey TW20 0EX, UK \\ ${ }^{2}$ Institute of Petroleum Engineering, Heriot-Watt University, Edinburgh, Scotland, UK \\ ${ }^{3}$ Integrated Ocean Drilling Program, Texas A\&M University, College Station, Texas, USA
}

Correspondence to: F. J. Hernández-Molina (javier.hernandez-molina@ rhul.ac.uk)

Received: 30 July 2013 - Revised: 1 October 2013 - Accepted: 21 October 2013 - Published: 5 November 2013

\begin{abstract}
IODP Expedition 339 drilled five sites in the Gulf of Cadiz and two off the west Iberian margin (November 2011 to January 2012), and recovered $5.5 \mathrm{~km}$ of sediment cores with an average recovery of $86.4 \%$. The Gulf of Cadiz was targeted for drilling as a key location for the investigation of Mediterranean outflow water (MOW) through the Gibraltar Gateway and its influence on global circulation and climate. It is also a prime area for understanding the effects of tectonic activity on evolution of the Gibraltar Gateway and on margin sedimentation. We penetrated into the Miocene at two different sites and established a strong signal of MOW in the sedimentary record of the Gulf of Cadiz, following the opening of the Gibraltar Gateway. Preliminary results show the initiation of contourite deposition at 4.2-4.5 Ma, although subsequent research will establish whether this dates the onset of MOW. The Pliocene succession, penetrated at four sites, shows low bottom current activity linked with a weak MOW. Significant widespread unconformities, present in all sites but with hiatuses of variable duration, are interpreted as a signal of intensified MOW, coupled with flow confinement. The Quaternary succession shows a much more pronounced phase of contourite drift development, with two periods of MOW intensification separated by a widespread unconformity. Following this, the final phase of drift evolution established the contourite depositional system (CDS) architecture we see today. There is a significant climate control on this evolution of MOW and bottom-current activity. However, from the closure of the Atlantic-Mediterranean gateways in Spain and Morocco just over $6 \mathrm{Ma}$ and the opening of the Gibraltar Gateway at 5.3 Ma, there has been an even stronger tectonic control on margin development, downslope sediment transport and contourite drift evolution. The Gulf of Cadiz is the world's premier contourite laboratory and thus presents an ideal testing ground for the contourite paradigm. Further study of these contourites will allow us to resolve outstanding issues related to depositional processes, drift budgets, and recognition of fossil contourites in the ancient record on shore. The expedition also verified an enormous quantity and extensive distribution of contourite sands that are clean and well sorted. These represent a relatively untapped and important exploration target for potential oil and gas reservoirs.
\end{abstract}

\section{Introduction and goals}

Integrated Ocean Drilling Program (IODP) Expedition 339 combined IODP Proposal 644-Full2 and ancillary proposal letter (APL)-763 (see Hodell et al., this issue). The expedition was primarily paleoceanographic in nature, focusing mainly on the broader significance of Mediterranean outflow water (MOW) on North Atlantic Ocean circulation and climate (Expedition 339 Scientists, 2012). This expedition offered a rare opportunity to understand the global link between paleoceanographic, climatic, and sea level changes from Messinian to the present and addressed the importance of ocean gateways in regional and global ocean circulation 


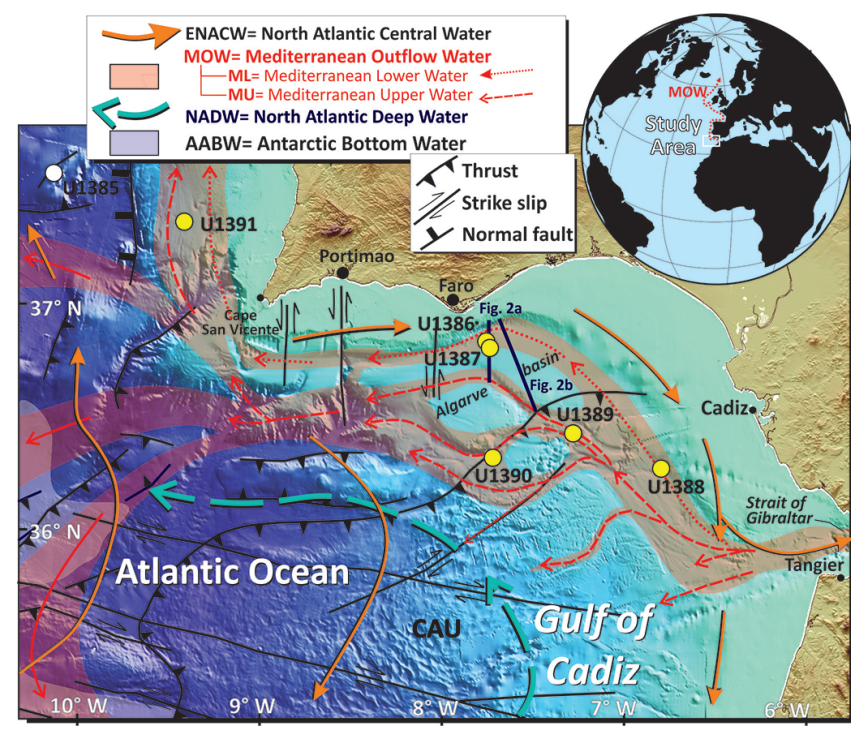

Figure 1. Expedition 339 sites in the Gulf of Cádiz and west Iberian margin, shown as yellow/white solid circles. Bottom water masses and ocean currents shown as NADW = North Atlantic deep water; $\mathrm{AABW}=$ Antarctic Bottom Water; ENACW = east North Atlantic common water; MOW = Mediterranean outflow water; MU, ML, $\mathrm{AI}=$ Atlantic Inflow.

and climate. Sites related to the Proposal 644-Full2 were specifically located in order to study the contourite depositional system (CDS) generated by the MOW influence in the Gulf of Cádiz and on the west Iberian margin (Fig. 1). In this paper we present a summary of the expedition goals, a regional background to the study area and the main preliminary results of the expedition.

The extensive CDS that has been developing within the Gulf of Cádiz and extending around the west Iberian margin over the past $5 \mathrm{My}$ is a direct result of MOW (e.g., Madelain, 1970; Gonthier et al., 1984; Faugères et al., 1985; Nelson et al., 1993, 1999; Llave et al., 2001, 2006, 2007, 2011; Stow et al., 2002, 2013a; Habgood et al., 2003; Hernández-Molina et al., 2003, 2006, 2011b; Mulder et al., 2003, 2006; Hanquiez et al., 2007; Marchès et al., 2007; Roque et al., 2012; Brackenridge et al., 2013). The high accumulation rates and expanded sedimentary records of drift deposits permit a highresolution examination of past environmental change (Llave et al., 2006; Voelker et al., 2006). The CDS deposits, therefore, hold the very best signal of MOW flow through the Strait of Gibraltar gateway and a clear record of its influence on the oceanography and climate of the North Atlantic Ocean and on the North Atlantic deep water (NADW) variability (Bigg and Wadley, 2001a, b; Bigg et al., 2003). However, the region had not previously been drilled for scientific purposes, even though the Gibraltar Gateway clearly has major implications for global climate and oceanography.

Expedition 339 was certainly ambitious in scope and scientifically very exciting. It was carefully crafted by a broad spectrum of scientists over at least a $9 \mathrm{yr}$ gestation period. The expedition reflects intense international interest in the region and its global significance, building on a research database accumulated over $35 \mathrm{yr}$. Furthermore, the study of the CDS should be of great interest to the international community not only because of its stratigraphic, sedimentologic, paleoceanographic, and paleoclimatologic significance but also because of its close relationship with possible specific deep-marine geohabitats and/or mineral and energy resources (Rebesco and Camerlenghi, 2008; HernándezMolina et al., 2011a). The next principal objectives of Expedition 339 address key elements of the IODP Initial Science Plan (ISP) through targeted drilling of a Neogene and Quaternary continental margin sequence in the Gulf of Cádiz and off West Iberia (Expedition 339 Scientists, 2012): (1) understand the opening of the Strait of Gibraltar as one of the main oceanic gateways worldwide and the onset of MOW; (2) determine MOW paleocirculation and its global climate significance; (3) identify external controls (climate and sea level changes) on sediment architecture; and (4) ascertain synsedimentary neotectonic control on architecture and evolution of the CDS.

\section{Geological and oceanographic setting}

The southwestern margin of the Iberian Peninsula, at the eastern segment of the Azores-Gibraltar fracture zone, is the location of the diffuse plate boundary between Eurasia (Iberia) and Africa (Nubia). The present plate convergence rate between the African and Eurasia plates in the Gulf of Cádiz area is $\sim 4 \mathrm{~mm} \mathrm{yr}^{-1}$ (e.g., Stich et al., 2006) with a WNW-ESE oblique convergence and is accommodated through a series of thrusts (Fig. 1) and dextral strikeslip faults (Zitellini et al., 2009). Distinct periods of crustal deformation, fault reactivation, and halokinesis related to the movement between Eurasia and Africa plates (e.g., Maldonado et al., 1999; Gutscher et al., 2002; Medialdea et al., 2004; Zitellini et al., 2009; Duarte et al., 2011, 2013) are known to have controlled the tectonostratigraphic evolution of this part of the Iberian Peninsula. The tectonic structure of this area is a consequence of the distinct phases of rifting since the Late Triassic to the Early Cretaceous related to the opening of the central and North Atlantic basins (Maldonado et al., 1999) and its later deformation during the Cenozoic, especially in the Miocene (Zitellini et al., 2009; Duarte et al., 2011). The Gulf of Cádiz straddles this oblique-convergence zone between the Eurasia and Africa plates, extending from the Gloria fault to the Gibraltar arc, which marks the western front of the Betic-Rif collisional orogen. Since the late Miocene, an oblique compressional regime has been regionally developed simultaneously with the extensional collapse of the Betic-Rif orogenic front, by westward emplacement of a giant chaotic body known as the Cadiz Allochthonous Unit (CAU) (Medialdea et al., 2004, 2009) or Gulf of Cadiz 


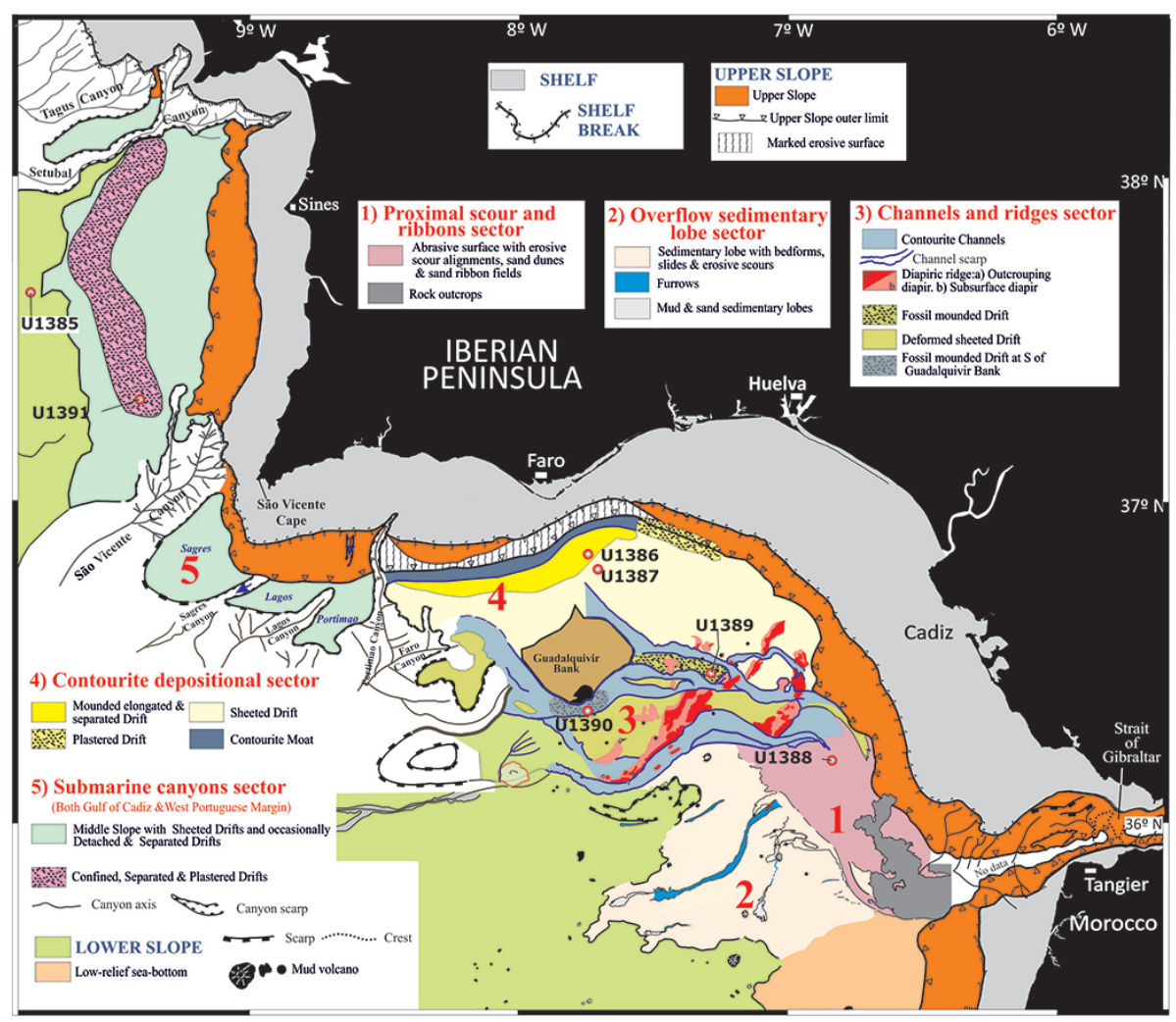

Figure 2. Regional map of the contourite depositional system on the middle slope of the Gulf of Cádiz and west Iberian margin with Expedition 339 site locations. Morphosedimentary sectors (1-5) based on Hernández-Molina et al. (2003, 2006) and S. Lebreiro (personel communication, 2006).

accrecionary prism (Gutscher et al., 2002) (former named "Olistostrome" by Maldonado et al., 1999), and by very high rates of basin subsidence coupled with strong diapiric activity (Maldonado et al., 1999; Alves et al., 2003; Terrinha et al., 2003, 2009; Zitellini et al., 2009; Roque et al., 2012). During the Pliocene and Quaternary, the effect of glacio-eustatic variations have partly overprinted structural effects on the margin and resulted in erosion, sedimentary progradation and incision of major submarine canyons. By the end of the lower Pliocene, subsidence decreased and the margin evolved towards its present more stable conditions (Maldonado et al., 1999; Alves et al., 2003; Medialdea et al., 2004; Llave et al., 2011; Roque et al., 2012). Some neotectonic reactivation is also evident as expressed by the occurrence of mud volcanoes and diapiric ridges, and fault reactivation (Zitellini et al., 2009).

Present-day circulation pattern in the Gulf of Cadiz is dominated by exchange of water masses through the Strait of Gibraltar (Fig. 2). This exchange is driven by the highly saline and warm MOW near the bottom and the turbulent, less saline, cool-water mass of Atlantic water at the surface. Regionally five water masses are identified: surface Atlantic water (SAW); eastern North Atlantic central water (ENACW); modified Antarctic intermediate water
(AAIW); MOW; and the NADW (Serra et al., 2010; Rogerson et al., 2012; Louarn and Morin, 2011). MOW forms a strong bottom current flowing toward the west and northwest above NADW. After it exits through the Gibraltar Gateway, MOW represents a flux of $\sim 1.78 \mathrm{~Sv}$ of intermediate water mass, which is warm and very saline that flows to the northwest along the middle slope under Atlantic inflow and above NADW generates important along-slope sedimentary processes along the Atlantic margin (see compilation on Hernández-Molina et al., 2011b). In the Gulf of Cádiz, MOW flows between 500 and $1400 \mathrm{~m}$ below sea level (m b.s.l.) with a velocity close to $300 \mathrm{~cm} \mathrm{~s}^{-1}$ at the Strait of Gibraltar and $\sim 80-100 \mathrm{~cm} \mathrm{~s}^{-1}$ at the latitude of Cape San Vicente. Its distribution is conditioned by the complex morphology of the continental slope, which generates two main cores (Fig. 2), between 500 and $700 \mathrm{~m}$ b.s.l. (upper core or Mediterranean upper water (MUW)) and 800 and $1400 \mathrm{~m}$ b.s.l. (lower core or Mediterranean lower water (MLW)). MLW is further divided into three branches. After exiting the Gulf of Cádiz, MOW has three principal branches, but one of them is flowing north around the Iberian margin reaching the Norwegian Sea (Iorga and Lozier, 1999).

The interaction of MOW with the Gulf of Cádiz and west off the coast of Portugal margin has resulted in the 


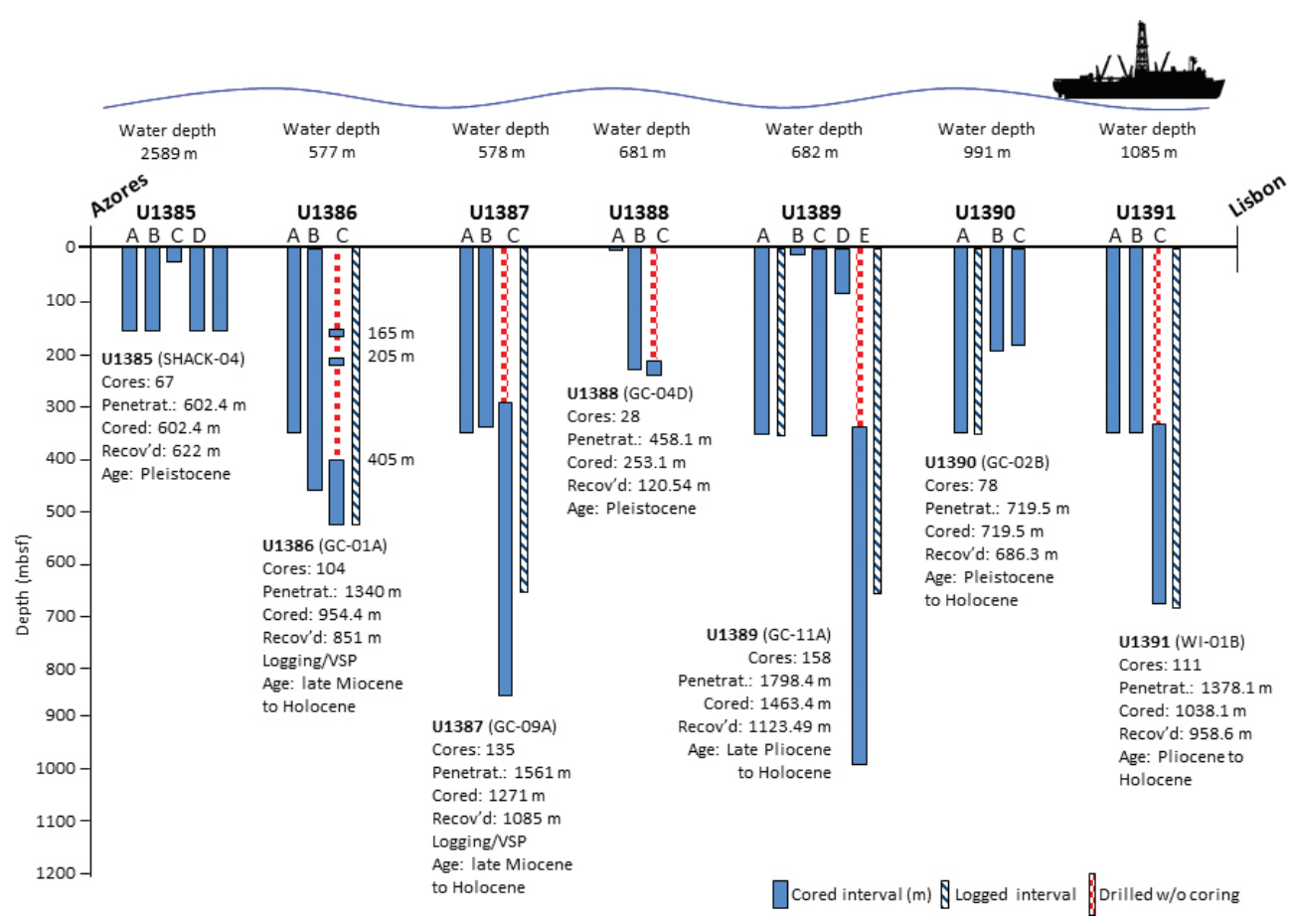

Figure 3. Expedition 339 sites information. 19 holes (681 cores) were drilled on 46.1 days on site, with a penetration of $7857.4 \mathrm{~m}$, cored 6301.6 and recovered $5446.7 \mathrm{~m}(86.4 \%)$.

development of one of the most extensive and complex CDSs ever described (Fig. 2). Many authors have highlighted this interaction and have characterized its features along the middle slope (e.g., Gonthier et al., 1984; Nelson et al., 1993, 1999; Llave et al., 2001, 2006, 2007, 2011; Habgood et al., 2003; Hernández-Molina et al., 2003, 2006; Mulder et al., 2003, 2006; Hanquiez et al., 2007; Marchès et al., 2007; Roque et al., 2012 among many other). Specific location of large depositional and erosional features within the CDS defines five morphosedimentary sectors (details in HernándezMolina et al., 2003, 2006), whose development is related to a systematic deceleration of MOW as it flows westward from the Strait of Gibraltar, caused by its interaction with margin bathymetry and the effects of Coriolis force. In general, the drifts are composed mainly of muddy, silty, and sandy sediments, with a mixed terrigenous and biogenic composition (Gonthier et al., 1984). In contrast, sand and gravel are found in the large contourite channels (Nelson et al., 1993, 1999; Stow et al., 2013a), as are many erosional features (Hernández-Molina et al., 2006, 2012). In the proximal sector close to the Strait of Gibraltar, an exceptionally thick $(\sim 815 \mathrm{~m})$ sandy-sheeted drift occurs, with sand layers averaging 12-15 m thick (Buitrago et al., 2001).

\section{Drilling expedition}

Expedition 339 drilled five sites in the Gulf of Cádiz (U1386-U1390) and two sites off the west Iberian margin
(U1385 and U1391) from 17 November 2011 to 17 January 2012 (http://iodp.tamu.edu, Fig. 1). Six of the sites, U1386U1391, were specifically selected in order to study the contourite depositional system (CDS) generated by MOW (Fig. 2).

Global Positioning System (GPS) coordinates from precruise site surveys were used to position the vessel at all Expedition 339 sites. A SyQuest Bathy 2010 CHIRP subbottom profiler was used to monitor the seafloor depth at each site to reconfirm the depth profiles from pre-cruise surveys. Once the vessel was positioned at a site, the thrusters were lowered and a positioning beacon was dropped to the seafloor. The dynamic positioning (DP) control of the vessel used navigational input from the GPS system and triangulation to the seafloor beacon, weighted by the estimated positional accuracy. The final hole position was the mean position calculated from the GPS data collected over a significant portion of the time the hole was occupied. A survey of the seafloor was conducted at all sites using the underwater camera system to ensure that it was free of obstructions.

All three standard coring systems - the advanced piston corer (APC), the extended core barrel (XCB), and the rotary core barrel (RCB) - were used during Expedition 339 (Stow et al., 2013b), which allowed us to drill 19 holes (681 cores) onboard the scientific drillship, D/V JOIDES Resolution on 46.1 days on site, with a penetration of $7857.4 \mathrm{~m}$, cored $6301.6 \mathrm{~m}$. In total, nearly $5.5 \mathrm{~km}$ of core were recovered, with 


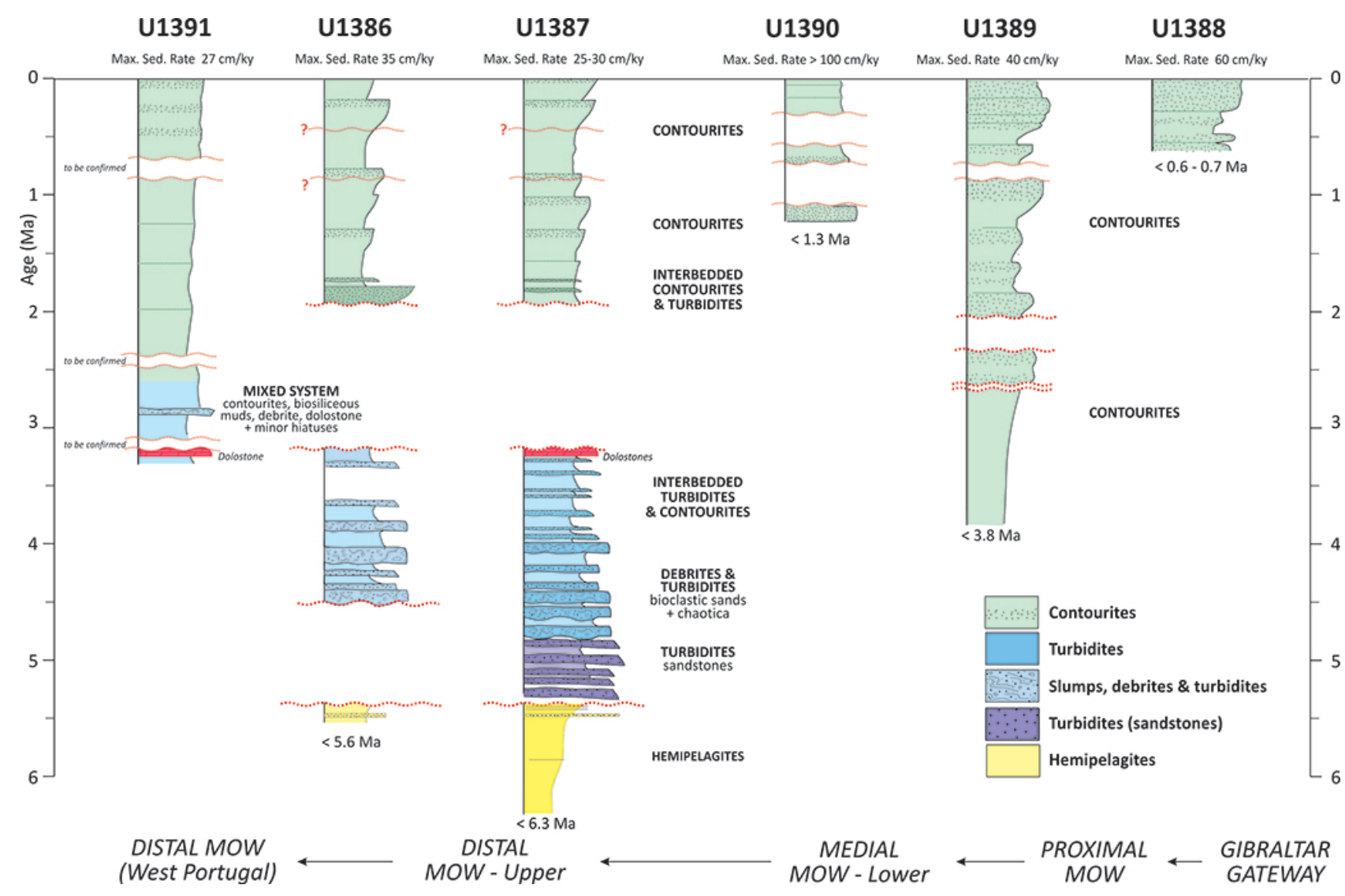

Figure 4. Lithologic summary for the sites drilled during IODP Expedition 339 in the Contourite Depositional System of the Gulf of Cadiz and west off Portugal. A general interpretation, including the position of principal hiatuses, is indicated. Age models are based on biostratigraphic datums and magnetostratigraphy. Sedimentation rates for the Pliocene $=15-25 \mathrm{~cm} \mathrm{ky}^{-1}$ and for the Quaternary $=\sim 30$ to $>100 \mathrm{~cm} \mathrm{ky}^{-1}$. Site location on Fig. 1 .

an average recovery of $86.4 \%$ (Fig. 3), from a region never before drilled for scientific purposes.

\section{Preliminary results}

The Gulf of Cádiz represents a key location for the investigation of MOW through the Gibraltar Gateway and its influence on global circulation and climate and is a prime area for understanding the effects of tectonic activity on evolution of the Gibraltar Gateway and on margin sedimentation. The Gulf of Cádiz has also become known as the world's premier contourite laboratory in which to thoroughly investigate and challenge existing models of contourite sedimentation. Extensive previous work, both on shore and offshore and including seismic surveys for oil company exploration, has allowed us to develop a good regional understanding. Most importantly, we have been able to establish a firm seismic stratigraphic framework into which we could fit the ages of key seismic horizons as determined by the drilling results from this expedition.
Shipboard biostratigraphic dating was achieved at all sites on the basis of first and last appearances of key marker species of calcareous nannofossils and planktonic foraminifers, as well as on one benthic foraminiferal datum. There is very close correspondence between biostratigraphic and magnetostratigraphic dating, which has allowed for dating certain important horizons, such as depositional hiatuses and boundaries between stratigraphic periods, and determined the sedimentary rates (Fig. 4). The principal drilled sediment facies present in the late Miocene to the present sedimentary record include pelagites, hemipelagites, contourites, turbidites, debrites and slump deposits (Figs. 4 and 5). Dolomitic mudstone and dolostone are rare facies that occur locally. Hemipelagic sedimentation dominates the late Miocene succession. Detail of these sedimentologic terms and their possible meaning could be found in Pickering et al. (1989), Reading (1996), Einsele (2000), Rebesco and Camerlenghi (2008), Hüneke and Mulder (2011) and Shanmugan (2012). The dominant sediment type at the CDS sites is contouritic, making up the $95 \%$ of the Quaternary and about $50 \%$ of the recovered Pliocene succession. This facies 
group includes sand-rich, muddy sand, silty mud and mudrich contourites, all of which were deposited at moderate $\left(20-30 \mathrm{~cm} \mathrm{ky}^{-1}\right)$ to very high $\left(>100 \mathrm{~cm} \mathrm{ky}^{-1}\right)$ rates of sedimentation.

The principal results of Expedition 339 can be summarized as follows (Stow et al., 2013b):

1. Mediterranean outflow water onset and evolution. We penetrated the Miocene at two different sites (Fig. 4) and established the strong signal of MOW in the sedimentary record of the Gulf of Cádiz following opening of the Gibraltar Gateway at 5.3 Ma. There is evidence for contourite deposition since the beginning of the Pliocene, but a stronger contourite signal begins at around 4.2-4.5 Ma. Nevertheless, even at this stage the MOW was not well developed and the signal is relatively weak. Additional seismic evidence for sheeted drift development exists in the early Pliocene. The contourite signal is also mixed with considerable downslope resedimentation and hiatuses in the record. The Pliocene succession was penetrated at four sites (Fig. 4), all of which show relatively low bottom-current activity linked with a generally weak MOW, with some evidence for a slow increase in activity through the later Pliocene. Significant unconformities are apparent at $\sim 3.0-3.2$ indicative of enhanced bottom currents related to intensified MOW. In the lower Quaternary an unconformity exists between 2.1-2.4 My to a variable extent at different sites, which represents the principal phase of MOW intensification from $\sim 2.4 \mathrm{Ma}$. Later, the Quaternary succession shows a much more general pronounced phase of contourite deposition and drift development throughout the region (Fig. 4). Although there is some variation between sites, we recognize two periods of current intensification, noted by increased sandy and silty contourites in the sedimentary record. The first is from $\sim 2.0$ to $0.9 \mathrm{Ma}$ and culminates in a regional hiatus of variable duration $(\sim 0.7-0.9 \mathrm{My})$. The second is from $0.9 \mathrm{Ma}$ to the present; this also includes a more locally developed hiatus at $\sim 0.4 \mathrm{Ma}$. Climate is one of the factors controlling this long-term long-period cyclicity in the development of MOW and bottom-current activity.

2. Tectonic pulse at a plate boundary. Regionally, there appears to be very strong tectonic control on margin development, downslope sediment transport, and contourite drift evolution. From the occurrence, nature, and disposition of the sedimentary record, as well as from the known timing of closure and opening of the AtlanticMediterranean gateways, we recognize a clear signal of this tectonic activity. We have established a clear signal of tectonic pulsing over the past $6 \mathrm{My}$ in this region that has controlled: (a) closure of Atlantic-Mediterranean connections in Spain and Morocco; (b) initial opening of the Strait of Gibraltar gateway and probable subsequent deepening; (c) continental margin instability and episodes of active downslope resedimentation; (d) basin subsidence in the Gulf of Cádiz; (e) local uplift and diapiric intrusion within the basin, and (f) constriction of MOW and development of narrow core bottom currents instead of a broad tabular flow. According to the timing of these different events, we hypothesize an $\sim 1$ My duration of tectonic pulsing (phases of major tectonic events) with an overprint of larger $\sim 2.5 \mathrm{My} \mathrm{cy-}$ cles, but further future investigations will test this idea.

3. Testing the contourite paradigm. Of the $5.5 \mathrm{~km}$ of core recovered, at least $4.5 \mathrm{~km}$ is from the Cádiz CDS, a natural contourite laboratory. This was the ultimate testing ground for the contourite paradigm. In general, we have found the models for contourite deposition to be in very good order. Sedimentation rates ranged from moderate $\left(\sim 20 \mathrm{~cm} \mathrm{k.y.}{ }^{-1}\right)$ to extremely high $\left(>100 \mathrm{~cm} \mathrm{k.y.}{ }^{-1}\right)$. The contourites recovered are remarkably uniform in composition and textural attributes. They have a noted absence of primary sedimentary structures and an intense continuous bioturbation throughout. They are particularly characterized by bi-gradational sequences from inverse to normal grading with a range of partial sequence types (Fig. 5), as predicted by the models. However, very interesting modifications are required, for example, to the detail of the sand-silt contributions and the role of sediment supply. These are very significant for future use of contourite systems in paleoceanographic studies and in hydrocarbon exploration. We have documented very interesting interactions between contourite and turbidite processes that are completely new and different from the current models.

4. Paradigm shift for oil exploration. We have verified an enormous quantity and extensive distribution of contourite sands (and bottom-current-modified turbidite sands), and have begun to establish their detailed characteristics (Fig. 5). Drilling at the proximal site (U1388) managed to penetrate only the uppermost $226 \mathrm{~m}$ of what we had interpreted as a very thick sandy contourite drift. Hole instability and collapse of these unconsolidated sands prevented further penetration. At other proximal sites (U1389 and U1390), we also encountered thick contourite sands (as thick as $10 \mathrm{~m}$ ) within the muddy contourite drifts. These are completely different deep water sands than the turbidite sands that are currently dominant as deep water oil and gas plays and are formed in different depositional settings, have different depositional architectures, and are clean and well sorted. These characteristics would provide good quality potential reservoirs when buried deeply. In addition, the associated contourite muds are very thick, rapidly deposited, and moderately rich in organic carbon (up to $2 \mathrm{wt} \%$ ). These could provide potential source rocks in the subsurface, as well as suitable seals in stratigraphic 


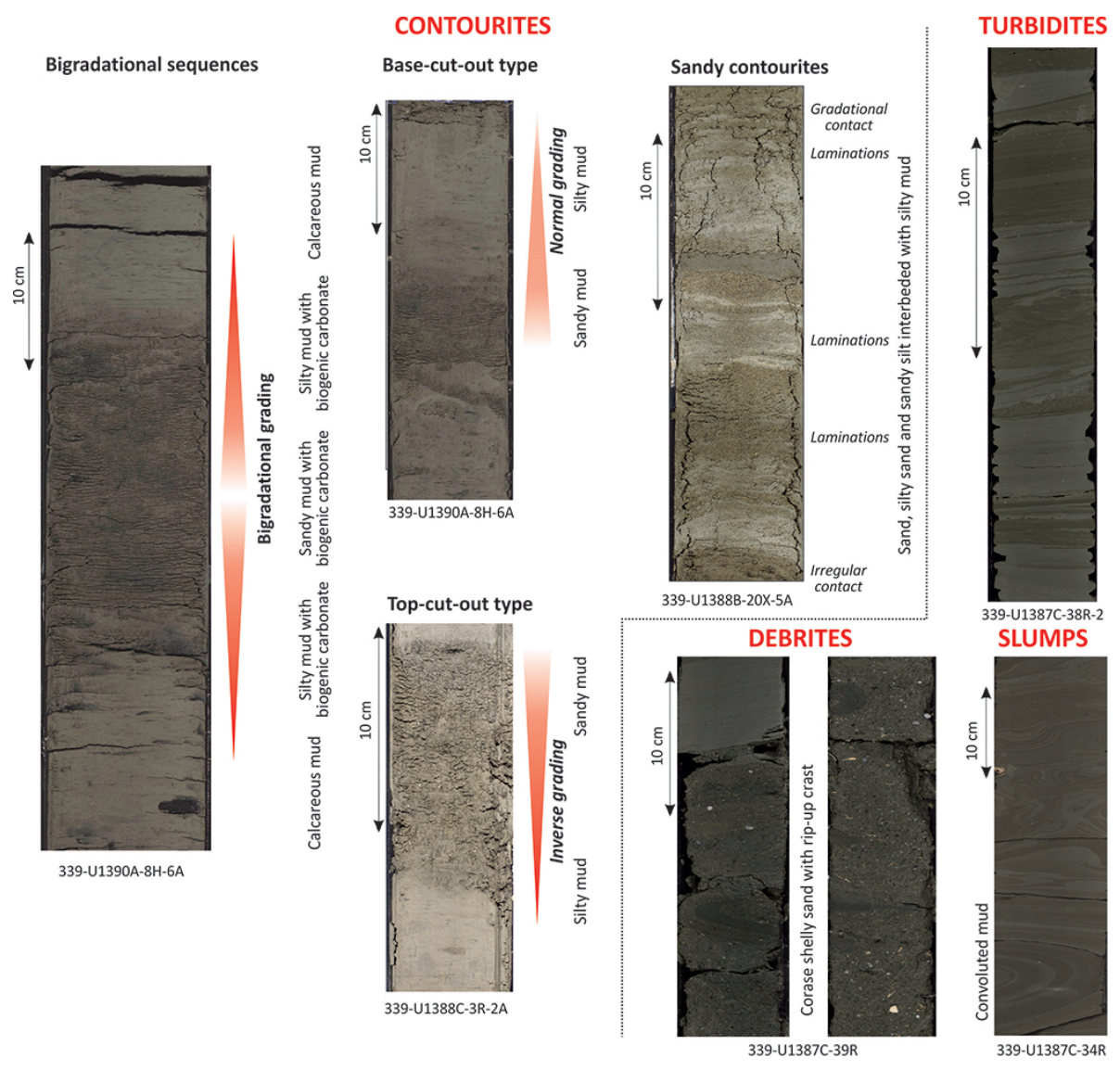

Figure 5. Examples of the principal sedimentary facies for contourites, turbidites, debrites and slumps recovered during IODP Expedition 339.

traps. These new findings could herald a paradigm shift in exploration targets in deep water settings.

\section{Expedition synthesis}

There can be no doubt that the expedition results have more than met our scientific objectives at the outset. The results are both expected in that they confirm many of our preexpedition hypotheses, and also unexpected in the wealth of new ideas and data that have arisen. We set out with broad objectives, which have been addressed and met as follows:

- Understanding of the opening of the Gibraltar Gateway and onset of MOW. We have drilled to the Miocene at two sites, assessed the basal age of drift sedimentation due to MOW, and evaluated the nature and effects of climate change in the patterns of drift sedimentation. We recognize clear evolution from proximal to distal sites.

- Determine MOW paleocirculation and global climate significance. We have penetrated most key Miocene to the present reflectors at one or several sites and have been able to date these reflectors and confirm or refine our seismic stratigraphic framework accordingly.
We have been able to understand and evaluate their link to paleocirculation variation and events with respect to MOW, as well as to the sedimentary and tectonic evolution of the whole region. We have recognized orbital and millennial-scale signals in the sedimentary record, which will be evaluated through subsequent work.

- Identify external controls on sediment architecture of the Gulf of Cadiz and Iberian margin. We have established the nature of sedimentation and timing of associated hiatuses by drilling and correlation between sites. This has enabled us to further refine our understanding of the stacking pattern and evolution of the Quaternary drift deposits, and to evaluate the nature of contourite cyclicity at different scales. Further detailed work on the contourite sediments will allow us to better understand the nature of the bottom current processes, contourite deposition and gain better insight into the sedimentary budget for contourite drifts. We have already established the key sources of sediment and their controls.

- Ascertain synsedimentary tectonic control on architecture and evolution of the CDS. There is a significant climate control on this evolution of MOW and 


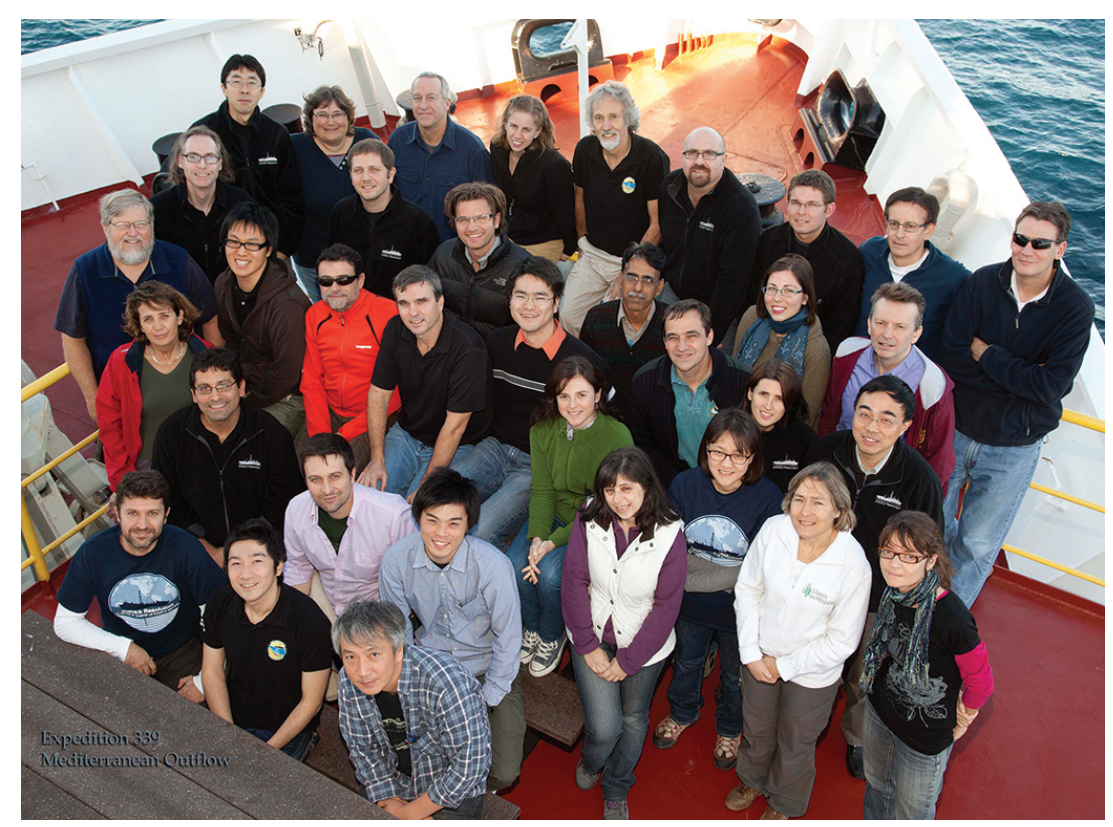

Figure 6. IODP Expedition 339 Scientists (Credit: John Beck, IODP/TAMU).

bottom-current activity. However, from the closure of the Atlantic-Mediterranean gateways in Spain and Morocco just over $6 \mathrm{Ma}$ and the opening of the Gibraltar Gateway at 5.3 Ma, there has been an even stronger tectonic control on margin development, downslope sediment transport and contourite drift evolution. Based on the timing of events recorded in the sedimentary record, we propose a tectonic pulsing in the region, linked with asthenosphere activity. We have been able to accurately chart the chronology of neotectonic activity in the Gulf of Cadiz and to clearly see evidence of the varied effects that this activity has had, both on the alongslope (contourite) depositional system and on the downslope component. The timing and local effects of diapiric activity have been established; further work will allow closer refinement and understanding of these effects and of rates of movement.

\section{Final considerations and post-expedition plans}

The Gulf of Cadiz is the world's premier contourite laboratory and thus presented an ideal testing ground for the contourite paradigm. Following examination of over $4.5 \mathrm{~km}$ of contourite cores, the existing models for contourite deposition are found to be in good working order. Their further study will allow us to resolve outstanding issues of depositional processes, drift budgets, and recognition of fossil contourites in the ancient records on shore. The expedition also verified an enormous quantity and extensive distribution of contourite sands that are clean and well sorted. These represent a completely new and important exploration target for potential oil and gas reservoirs (e.g., Viana and Rebesco, 2007; Viana, 2008; Stow and Fauguères, 2008; Shanmugan, 2006, 2012, 2013; Brackenridge et al., 2013; Stow et al., 2013a). Preliminary work has shown a remarkable record of orbital-scale variation in bulk sediment properties of contourites at several of the drift sites and a good correlation between all sites. The tectonic and climate control on contourite sedimentation is clearly significant at long and middle scale, but further work will determine the nature of controls at the short scale (millennial scale).

After the expedition, the first post-cruise meeting was in April 2012 (College Station, USA) and the sampling party in June 2012 (Bremen, Germany). Currently, therefore, the IODP Expedition 339 scientists are working in more detail combining sample analyses, geophysical and well data to decode the ancient deposits and processes related to the MOW circulation. Results will be presented in the second post-cruise meeting in Tarifa (Cádiz, Spain), in June 2014. In parallel, two international actions are being planned related to the IODP-339: (a) "Deep-water Circulation: Processes and Product" in September 2014 at Renard Centre of Marine Geology, Ghent University (Belgium); and (b) a collaboration is being established with the MEDGATE Network (EU-funded Marie Curie Initial Training Network) for reconstructing Mediterranean-Atlantic exchange (http://www. eu-medgate.net) for organizing a meeting between 5-8 May 2015 in Rabat (Morocco). 


\section{The IODP Expedition 339 scientific party}

Co-chiefs of the Expedition-339 are Dorrik Stow, (ECOSSE, Heriot-Watt Univ., UK) and F. Javier Hernández-Molina (Royal Holloway University of London, UK), and the USIO Expedition Project Manager is Carlos Alvarez Zarikian (Texas A\&M University, USA). Thirty-four members form the scientific party (http://iodp.tamu.edu/scienceops/ precruise/medoutflow/participants.html), which belong to 13 countries and four continents (Fig. 6): Europe (14 researchers); USA (11); Japan (6); Australia (1); Korea (1); China (1) and India (1). In Europe researchers come from Spain (4); UK (2); France (3); Portugal (2); Germany (1); the Netherlands (1); and Austria (1). They cover different research specialities including wireline logging; sedimentology; stratigraphic correlation; sediment physical properties; geochemisty, micropaleontology; and people for outreach and education.

\section{IODP Expedition 339 Scientists}

F. J. Hernández-Molina (RHUL, UK), D. A. V. Stow (HeriotWatt Univ., UK), C. Alvarez-Zarikian (IODP-Texas A\&M Univ., USA), G. Acton (Univ. of California-Davis, USA), A. Bahr (Univ. of Frankfurt, Germany), B. Balestra (Univ. California Santa Cruz, USA), E. Ducassou (Univ. de Bordeaux I, France), R. Flood (Stony Brook Univ., USA), J.A. Flores (Univ. de Salamanca, Spain), S. Furota (Hokkaido Univ., Japan), P. Grunert (Univ. of Graz, Austria), D. Hodell (Univ. of Cambridge, UK), F. Jimenez-Espejo (JAMSTEC, Japan), J. K. Kim (Korea Ocean Research and Development Institute, Korea), L. Krissek (Ohio State University, USA), J. Kuroda (JAMSTEC, Japan), B. Li (Nanjing Institute of Geology and Palaeontology, P.R. China), E. Llave (IGME, Spain), J. Lofi (Univ. Montpellier II, France), L. Lourens (Utrecht University, the Netherlands), M. Miller (California Institute of Technology, USA), F. Nanayama (Geological Survey of Japan, Japan), Naohisa Nishida (Geological Survey of Japan, Japan), C. Richter (Univ. of Louisiana, USA), C. Roque (IPMA, Portugal), H. Pereira (Escola Secundária de Loulé, Portugal), M. Fernanda Sanchez Goñi (Univ. de Bordeaux I, France), F. J. Sierro (Univ. de Salamanca, Spain), A. D. Singh (Banaras Hindu University, India), C. Sloss (Queensland University of Technology, Australia), Y. Takashimizu (Niigata University, Japan), A. Tzanova (Brown University, USA), A. Voelker (LNEG, Portugal), T. Williams (LDEO, Columbia Univ., USA) and C. Xuan (Oregon State University, USA)

\section{Supplementary material related to this article is available online at http://www.sci-dril.net/16/1/2013/ sd-16-1-2013-supplement.zip.}

Acknowledgements. We thank the drilling crew, ship's crew, and scientific and technical staff of the drillship D/V JOIDES Resolution without whom IODP Expedition 339 would not have been possible. We are very grateful to REPSOL and TGS-NOPEC for allowing us to use a large unpublished data set of seismic records and well results from the Gulf of Cádiz and west off the coast of Portugal. This research is also partially supported through the Project CTM 2008-06399-C04/MAR (CONTOURIBER), CTM 2012-39599-C03 (MOWER Project), IGCP-619 and INQUA 1204 Projects. Finally, we also thank Gabriel Filippelli and Serge Berne for their interest and suggestions, which have helped us to improve the final version of our manuscript.

Edited by: G. Camoin

Reviewed by: G. Filippelli and S. Berne

\section{References}

Alves, T. M., Gawthorpe, R. L., Hunt, D. W., and Monteiro, J. H.: Cenozoic tectono-sedimentary evolution of the western Iberian margin, Mar. Geol., 195, 75-108, doi:10.1016/S00253227(02)00683-7, 2003.

Bigg, G. R. and Wadley, M. R.: Millenial-scale variability in the oceans: an ocean modelling view, J. Quaternary Sci., 16, 309319, doi:10.1002/jqs.599, 2001a.

Bigg, G. R. and Wadley, M. R.: The origin and flux of icebergs released into the Last Glacial Maximum Northern Hemisphere oceans: the impact of ice-sheet topography, J. Quaternary Sci., 16, 565-573, doi:10.1002/jqs.628, $2001 \mathrm{~b}$.

Bigg, G. R., Jickells, T. D., Liss, P. S., and Osborn, T. J.: The role of the oceans in climate, Int. J. Climatol.,, 23, 1127-1159, doi:10.1002/joc.926, 2003.

Brackenridge, R. A., Hernández-Molina, F. J., Stow, D. A. V., and Llave, R.: A Pliocene mixed contourite-turbidite system offshore the Algarve Margin, Gulf of Cadiz: Seismic response, margin evolution and reservoir implications, Mar. Petrol. Geol., 46, 3650, doi:10.1016/j.marpetgeo.2013.05.015, 2013.

Buitrago, J., García, C., Cajebread-Brow, J., Jiménez, A., and Martínez del Olmo, W.: Contouritas: Un Excelente Almacén Casi Desconocido (Golfo de Cádiz, SO de España) [Congreso Técnico Exploración y Producción REPSOL-YPF, Madrid, 24-27 September 2001], 2001.

Duarte, J. C., Rosas, F. M., Terrinha, P., Gutscher, M.-A., Malavieille, J., Silva, S., and Matias, L.: Thrust-wrench interference tectonics in the Gulf of Cadiz (Africa-Iberia plate boundary in the North-East Atlantic): Insights from analog models, Mar. Geol., 289, 135-149, 2011.

Duarte, J. C., Rosas, F. M., Terrinha, P., Schellart, W. P., Boutelier, D., Gutscher, M. A., and Ribeiro, M. A.: Are subduction zones invading the Atlantic? Evidence from the southwest Iberia margin, Geology, doi:10.1130/G34100.1, in press, 2013.

Einsele, G.: Sedimentary Basins. Evolution, Facies, and Sediment Budget, 2nd Edn., Springer-Verlag, Berlin, 792 pp., 2000.

Expedition 339 Scientists: Mediterranean outflow: environmental significance of the Mediterranean Outflow Water and its global implications, IODP Prel. Rept.,, 339, doi:10.2204/iodp.pr.339.2012, 2012.

Faugères, J.-C., Frappa, M., Gonthier, E., de Resseguier, A., and Stow, D.: Modelé et facies de type contourite à la surface d'une 
ride sédimentaire édifiée par des courants issus de la veine d'eau méditerranéenne (ride du Faro, Golfe de Cadix), Bull. Soc. Geol. Fr., 1, 35-47, 1985.

Gonthier, E. G., Faugeres, J. C., and Stow, D. A. V.: Contourite facies of the Faro Drift, Gulf of Cádiz, in: Fine-Grained Sediments: Deep Water Processes and Facies, edited by: Stow, D. A. V. and Piper, D. J. W., Geol. Soc. Spec. Publ., 15, 275-292, doi:10.1144/GSL.SP.1984.015.01.18, 1984.

Gutscher, M.-A., Malod, J., Rehault, J.-P., Contrucci, I., Klingelhoefer, F., Mendes-Victor, L., and Spakman, W.: Evidence for active subduction beneath Gibraltar, Geology, 30, 1071-1074, doi:10.1130/0091-7613(2002)030<1071:EFASBG > 2.0.CO;2, 2002.

Habgood, E. L., Kenyon, N. H., Masson, D. G., Akhmetzhanov, A., Weaver, P. P. E., Gardner, J., and Mulder, T.: Deep-water sediment wave fields, bottom current sand channels, and gravity flow channel-lobe systems: Gulf of Cádiz, NE Atlantic, Sedimentology, 50, 483-510, doi:10.1046/j.1365-3091.2003.00561.x, 2003.

Hanquiez, V., Mulder, T., Lecroart, P., Gonthier, E., Marchès, E., and Voisset, M.: High resolution seafloor images in the Gulf of Cádiz, Iberian margin, Mar. Geol., 246, 42-59, doi:10.1016/j.margeo.2007.08.002, 2007.

Hernández-Molina, F. J., Llave, E., Stow, D. A. V., García, M., Somoza, L., Vázquez, J. T., Lobo, F. J., Maestro, A., Díaz del Río, V., León, R., Medialdea, T., and Gardner, J.: The contourite depositional system of the Gulf of Cádiz: a sedimentary model related to the bottom current activity of the Mediterranean Outflow Water and its interaction with the continental margin, Deep-Sea Res. Pt. II, 53, 1420-1463, doi:10.1016/j.dsr2.2006.04.016, 2006.

Hernández-Molina, F. J., Stow, D. A. V., Llave, E., Rebesco, M., Ercilla, G., Van Rooij, D., Mena, A., Váquez, J. T., and Voelker, A.: Deep-water Circulation: Processes \& Products (16-18 June 2010, Baiona): an introduction and future challenges, Geo-Mar. Lett., SI Baiona, Deep Water Circulation: processes and products, 31, 285-300, doi:10.1007/s00367-011-0261-z, 2011a.

Hernández-Molina, F. J., Serra, N., Stow, D. A. V., Llave, L., Ercilla, E., and Van Rooij, D.: Along-slope oceanographic processes and sedimentary products around the Iberian margin, Geo-Mar. Lett., 31, 315-341, 2011b.

Hernández-Molina, F. J., Llave, E., Fontan, A., Brackenridge, R. E., Stow, D. A. V., Ercilla, G., Medialdea, T., García, M., Sandoval, N., Preu, B., Arlucea, M. P., Nombela, M. A., Alejo, I., Francés, G., Mena, A., Casas, D., Somoza, L., León, R., Vázquez, J. T., Juan, C., Van Rooij, D., Matias, H., Bruno, M., Serra, N., and CONTOURIBER Team: First evidence of a main channel generated by the Mediterranean Outflow Water after its exit from the Gibraltar Strait, Geo-Temas, 13, 1-4, 2012.

Hernández-Molina, J., Llave, E., Somoza, L., Fernández-Puga, M. C., Maestro, A., León, R., Medialdea, T., Barnolas, A., García, M., Díaz del Río, V., Fernández-Salas, L. M., Vázquez, J. T., Lobo, F., Alveirinho Dias, J. M., Rodero, J., and Gardner, J.: Looking for clues to paleoceanographic imprints: a diagnosis of the Gulf of Cádiz contourite depositional systems, Geology, 31, 19-22, doi:10.1130/00917613(2003)031<0019:LFCTPI>2.0.CO;2, 2003.

Hüneke, H. and Mulder, T.: Deep-Sea Sediments (Developments in Sedimentology), Elsevier Science, 750 pp., 2011.

Iorga, M. C. and Lozier, M. S.: Signatures of the Mediterranean Outflow from a North Atlantic climatology - 1. Salinity and density fields, J. Geophys. Res.-Oceans, 104, 25985-26029, doi:10.1029/1999JC900115, 1999.

Llave, E., Hernández-Molina, F. J., Somoza, L., Díaz del Río, V., Stow, D. A. V., Maestro, A., and Alveirinho Dias, J. M.: Seismic stacking pattern of the Faro-Albufeira contourite system (Gulf of Cádiz): a Quaternary record of paleoceanographic and tectonic influences, Mar. Geophys. Res., 22, 487-508, doi:10.1023/A:1016355801344, 2001.

Llave, E., Schönfeld, J., Hernández-Molina, F. J., Mulder, T., Somoza, L., Díaz del Río, V., and Sánchez-Almazo, I.: Highresolution stratigraphy of the Mediterranean Outflow contourite system in the Gulf of Cádiz during the late Pleistocene: the impact of Heinrich events, Mar. Geol., 227, 241-262, doi:10.1016/j.margeo.2005.11.015, 2006.

Llave, E., Hernández-Molina, F. J., Somoza, L., Stow, D. A. V., and Díaz Del Río, V.: Quaternary evolution of the contourite depositional system in the Gulf of Cádiz, Geol. Soc. Spec. Publ., 276, 49-79, doi:10.1144/GSL.SP.2007.276.01.03, 2007.

Llave, E., Matias, H., Hernández-Molina, F. J., Ercilla, G., Stow, D. A. V., and Medialdea, T.: Pliocene-Quaternary contourites along the northern Gulf of Cadiz margin: sedimentary stacking pattern and regional distribution, Geo-Mar. Lett., 31, 377-390, doi:10.1007/s00367-011-0241-3, 2011.

Louarn, E. and Morin, P.: Antarctic Intermediate Water influence on Mediterranean Sea Water outflow, Deep-Sea Res. Pt. I, 58, 932-942, doi:10.1016/j.dsr.2011.05.009, 2011.

Madelain, F.: Influence de la topographie du fond sur l'écoulement méditerranéen entre le Détroit de Gibraltar et le Cap SaintVincent, Cah. Oceanogr., 22, 43-61, 1970.

Maldonado, A., Somoza, L., and Pallarés, L.: The Betic orogen and the Iberian-African boundary in the Gulf of Cádiz: geological evolution (central North Atlantic), Mar. Geol., 155, 9-43, doi:10.1016/S0025-3227(98)00139-X, 1999.

Marchès, E., Mulder, T., Cremer, M., Bonnel, C., Hanquiez, V., Gonthier, E., and Lecroart, P.: Contourite drift construction influenced by capture of Mediterranean Outflow Water deep-sea current by the Portimão submarine canyon (Gulf of Cádiz, South Portugal), Mar. Geol., 242, 247-260, doi:10.1016/j.margeo.2007.03.013, 2007.

Medialdea, T., Vegas, R., Somoza, L., Vázquez, J. T., Maldonado, A., Díaz-del-Río, V., Maestro, A., Córdoba, D., and FernándezPuga, M. C.: Structure and evolution of the "Olistostrome" complex of the Gibraltar Arc in the Gulf of Cádiz (eastern Central Atlantic): evidence from two long seismic cross-sections, Mar. Geol., 209, 173-198, doi:10.1016/j.margeo.2004.05.029, 2004.

Medialdea, T., Somoza, L., Pinheiro, L. M., Fernández-Puga, M. C., Vázquez, J. T., León, R., Ivanov, M. K., Magalhaes, V., Díaz del Río, V., and Vegas, R.: Tectonics and mud volcano development in the Gulf of Cádiz, Mar. Geol., 261, 48-63, doi:10.1016/j.margeo.2008.10.007, 2009.

Mulder, T., Voisset, M., Lecroart, P., Le Drezen, E., Gonthier, E., Hanquiez, V., Faugères, J.-C., Habgood, E., Hernandez-Molina, F. J., Estrada, F., Llave-Barranco, E., Poirier, D., Gorini, C., Fuchey, Y., Volker, A., Freitas, P., Lobo Sanchez, F., Fernandez, L. M., and Morel, J.: The Gulf of Cádiz: an unstable giant contouritic levee, Geo-Mar. Lett., 23, 7-18, doi:10.1007/s00367003-0119-0, 2003.

Mulder, T., Lecroart, P., Hanquiez, V., Marches, E., Gonthier, E., Guedes, J.-C., Thiébot, E., Jaaidi, B., Kenyon, N., Voisset, M., 
Perez, C., Sayago, M., Fuchey, Y., and Bujan, S.: The western part of the Gulf of Cádiz: contour currents and turbidity currents interactions, Geo-Mar. Lett., 26, 31-41, doi:10.1007/s00367005-0013-z, 2006.

Nelson, C. H., Baraza, J., and Maldonado, A.: Mediterranean undercurrent sandy contourites, Gulf of Cádiz, Spain, Sediment. Geol., 82, 103-131, doi:10.1016/0037-0738(93)90116-M, 1993.

Nelson, C. H., Baraza, J., Maldonado, A., Rodero, J., Escutia, C., Barber Jr., J. H.: Influence of the Atlantic inflow and Mediterranean outflow currents on late Quarternary sedimentary facies of Gulf of Cádiz continental margin, Mar. Geol., 155, 99-129, doi:10.1016/S0025-3227(98)00143-1, 1999.

Pickering, K. T., Hiscott, R. N., and Hein, F. J.: Deep Marine Environments. Clastic Sedimentation and Tectonics, Unwin Hyman Ltd., London, 416 pp., 1989.

Reading, H. G. (Ed.): Sedimentary Environments. Processes, Facies and Stratigraphy, 3rd Edn., Blackwell Science, 688 pp., 1996.

Rebesco, M. and Camerlenghi, A. (Eds.): Contourites, Dev. Sedimentol., 60, 688 pp., 2008.

Rogerson, M., Rohling, E. J., Bigg, G. R., and Ramirez, J.: Paleoceanography of the Atlantic-Mediterranean exchange: Overview and first quantitative assessment of climatic forcing, Rev. Geophys., 50, RG2003, doi:10.1029/2011RG000376, 2012.

Roque, C., Duarte, H., Terrinha, P., Valadares, V., Noiva, J., Cachão, M., Ferreira, J., Legoinha, P., and Zitellini, N.: Pliocene and Quaternary depositional model of the Algarve margin contourite drifts (Gulf of Cadiz, SW Iberia): seismic architecture, tectonic control and paleoceanographic insights, Mar. Geol., 303-306, 42-62, 2012.

Serra, N., Ambar, I., and Boutov, D.: Surface expression of Mediterranean Water dipoles and their contribution to the shelf/slope open ocean exchange, Ocean Sci., 6, 191-209, doi:10.5194/os6-191-2010, 2010.

Shanmugam, G.: Deep-Water Processes and Facies Models: Implications for Sandstone Petroleum Reservoirs: 5 (Handbook of Petroleum Exploration and Production), Elsevier Science, 496 pp., 2006.

Shanmugam, G.: New perspectives on deep-water sandstones: origin, recognition, initiation and reservoir quality, Handbook of Petroleum Exploration and Production, Vol. 9, Elsevier, Amsterdam, p. 524, 2012.

Shanmugam, G.: Modern internal waves and internal tides along oceanic pycnoclines: Challenges and implications for ancient deep-marine baroclinic sands, AAPG Bull., 97, 767-811, 2013.

Stich, D., Serpelloni, E., Mancilla, F.-L., and Morales, J.: Kinematics of the Iberia-Maghreb plate contact from seismic moment tensors and GPS observations, Tectonophysics, 426, 295-317, 2006.
Stow, D. A. V. and Faugères, J. C.: Contourite facies and the facies model, in: Contourites, Developments in Sedimentology, edited by: Rebesco, M. and Camerlenghi, A., 60, Elsevier, 223-256, 2008.

Stow, D. A. V., Faugères, J.-C., Gonthier, E., Cremer, M., Llave, E., Hernández-Molina, F. J., Somoza, L., and Díaz del Río, V.: Faro-Albufeira drift complex, northern Gulf of Cádiz, Mem.-Geol. Soc. London, 22, 137-154, doi:10.1144/GSL.MEM.2002.022.01.11, 2002.

Stow, D. A. V., Hernández-Molina, F. J., Llave, E., Bruno, M., García, M., Díaz del Río, V., Somoza, L., and Brackenridge, R. E.: The Cadiz Contourite Channel: Sandy contourites, bedforms and dynamic current interaction, Mar. Geol., 343, 99-114, $2013 \mathrm{a}$.

Stow, D. A. V., Hernández-Molina, F. J., Alvarez Zarikian, C. A., and the Expedition 339 Scientists: Proc. IODP, 339: Tokyo (Integrated Ocean Drilling Program Management International, Inc.), doi:10.2204/iodp.proc.339.2013, 2013b.

Terrinha, P., Pinheiro, L. M., Henriet, J.-P., Matias, L., Ivanov, M. K., Monteiro, J. H., Akhmetzhanov, A., Volkonskaya, A., Cunha, T., Shaskin, P., and Rovere, M.: Tsunamigenic-seismogenic structures, neotectonics, sedimentary processes, and slope stability on the southwest Portuguese margin, Mar. Geol., 195, 55-73, doi:10.1016/S0025-3227(02)00682-5, 2003.

Terrinha, P., Matias, L., Vicente, J., Duarte, J., Luís, J., Pinheiro, L., Lourenço, N., Diez, S., Rosas, F., Magalhães, V., Valadares, V., Zitellini, N., Roque, C., Mendes Víctor, L., and MATESPRO Team: Morphotectonics and strain partitioning at the Iberia-Africa plate boundary from multibeam and seismic reflection data, Mar. Geol., 267, 156-174, doi:10.1016/j.margeo.2009.09.012, 2009.

Viana, A.: Economic relevance of contourites, in: Contourites. Developments in Sedimentology, edited by: Rebesco, M. and Camerlenghi, A., Vol. 60., Elsevier, Amsterdam, 493-510, 2008.

Viana, A. and Rebesco, M. (Eds.): Economic and Paleoceanographic Significance of Contourites, Geological Society London Special Publication 276, 350 pp., 2007.

Voelker, A. H. L., Lebreiro, S. M., Schönfeld, J., Cacho, I., Erlenkeuser, H., and Abrantes, F.: Mediterranean Outflow strengthening during Northern Hemisphere coolings: a salt source for the glacial Atlantic?, Earth Planet. Sc. Lett., 245, 39-55, doi:10.1016/j.epsl.2006.03.014, 2006.

Zitellini, N., Gràcia, E., Matias, L., Terrinha, P., Abreu, M. A., DeAlteriis, G., Henriet, J. P., Dañobeitia, J. J., Masson, D. G., Mulder, T., Ramella, R., Somoza, L., and Diez, S.: The quest for the Africa-Eurasia plate boundary west of the Strait of Gibraltar, Earth Planet. Sc. Lett., 280, 13-50, doi:10.1016/j.eps1.2008.12.005, 2009. 